\title{
Isolation and cytotoxicity of puberulonic acid from Penicillium resticulosum
}

\author{
Miyoshi IKawA*1, Takashi Tatsuno*2, Hiroshi TsunodA*2, \\ and Makoto UMEDA*3 \\ 井川美好*1 ・唇野高司*2 ・角田 廣*2 ・梅田 誠*3 : Penicillium resticulosum \\ からのプベルロン酸の分離とその細胞毒性について
}

Puberulonic acid (I) was isolated by Birkinshaw and Raistrick ${ }^{1)}$ from Penicillium puberulum Bainier and Penicillium aurantio-virens Biourge grown on Czapek-Dox glucose medium and its

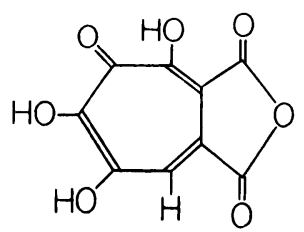

structure determined by Aulin-Erdtman 2). In this paper we wish to report the isolation of puberulonic acid from Penicillium resticulosum Birkinshaw, Raistrick \& Smith and the cytotoxic properties of the puberulonic acid against HeLa cells. Previous studies have indicated the cytotoxic effects of synthetic puberulonic acid against HeLa cells ${ }^{3)}$.

Penicillium resticulosum was grown in Petri dishes on Czapek-Dox medium containing 5\% sucrose, $0.3 \%$ yeast extract, and $2 \%$ agar. At the end of 6 days at room temperature, when the agar side of the mold colony was a brilliant yellow, the contents from 40 plates were extracted with $900 \mathrm{ml}$ of acetone in a blendor. The mixture was filtered by suction, giving an orangeyellow filtrate, and the residue extracted again with $300 \mathrm{ml}$ of acetone. The extracts were combined and concentrated to dryness in vacuo. The orange residue was treated with a small volume of hot methanol, filtered, and the insoluble residue washed with a small volume of methanol. An orange methanol-insoluble powder $(369 \mathrm{gm})$ was obtained. The powder $(77 \mathrm{mg})$ was dissolved in $5 \mathrm{ml}$ of $5 \% \mathrm{NaHCO}_{3}$ and filtered. The filtrate was acidified to $\mathrm{pH} 1-2$ with concentrated $\mathrm{HCl}$ and extracted repeatedly with $15 \mathrm{ml}$ portions of ethyl acetate until the ethyl acetate

*1 Department of Biochemistry, University of New Hampshire (Durham, New Hampshire, U.S.A. 03824). On leave at the Institute of Physical and Chemical Research. This work was made possible in part by a grant from the National Science Foundation under the United States-Japan Cooperative Science Program.

*2 Institute of Physical and Chemical Research (Hirosawa, Wako-shi, Saitama 351)

理化学研究所 (广351 埼玉県和光市広沢 2)

*3 Tissue Culture Laboratory, Yokohama City University School of Medicine (Urafune-cho, Minami-ku, Yokohama 232)

横浜市立大学医学部 (千232 横浜市南区浦舟町) 
was almost colorless, 6 extractions being necessary. The extracts were combined, filtered, and concentrated in vacuo to dryness, yielding $51 \mathrm{mg}$ of a crystalline residue, which was recrystallized from ethyl acetate to give $16 \mathrm{mg}$ of brilliant yellow crystals.

Analysis: Found- $\mathrm{C}, 48.6 \% ; \mathrm{H}, 2.2 \%$. Calculated for $\mathrm{C}_{9} \mathrm{H}_{4} \mathrm{O}_{7}$ (puberulonic acid)- C, $48.2 \% ; \mathrm{H}, 1.8 \%$.

The crystals melted at $290-300^{\circ}$. Brikinshaw and Raistrick ${ }^{1)}$ report $296^{\circ} \mathrm{d}$ for puberulonic acid. The IR spectrum ( $\mathrm{KBr}$ pellet) showed very strong anhydride $\mathrm{C}=\mathrm{O}$ stretching bands at 1820 and $1760 \mathrm{~cm}^{-1}$, and the spectrum agreed with the IR spectrum reported by Aulin-Erdtman and Theorell4) for puberulonic acid. The UV-visible spectrum in $1 \mathrm{M} \mathrm{HCl}$ was identical with that reported by Aulin-Erdtman'). It can therefore be concluded that the bright yellow pigment produced by $P$. resticulosum is puberulonic acid.

Cytotoxicity tests against HeLa cells were carried out as previously described ${ }^{3)}$. At 100 $\mu \mathrm{g} / \mathrm{ml}$, cell damage was scored as 4 (complete cytolysis); at $32 \mu \mathrm{g} / \mathrm{ml}$, as 3.5 ; at $10 \mu \mathrm{g} / \mathrm{ml}$, as 2 ; and at $3.2 \mu \mathrm{g} / \mathrm{ml}$, as 0 (no cell damage). Morphological changes observed were enlarged nuclei and nucleoli. A few multinuclear cells were observed. Although puberulonic acid appeared to be more toxic than rubratoxin $\mathrm{B}$, which also contains the 5 -membered anhydride ring, the morphological changes were less conspicuous than those caused by $\mathrm{B}$.

\section{Summary}

Puberulonic acid was isolated from a culture of Penicillium resticulosum and shown to possess cytotoxic activity against HeLa cells.

\section{References}

1) Birkinshaw, J. H., and Raistrick, H.: Biochem. J. 26, 441 (1932).

2) Aulin-Erdtman, G.: Acta Chem. Scand : 5, 301 (1951).

3) Umeda, M., Yamashita, T., Saito, M., Sekita, S., Takahashi, C., Yoshihira, K., Natori, S., Kurata, H., and Udagawa, S.: Japan. J. Exp. Med: 44, 83 (1974).

4) Aulin-Erdtman, G., and Theorell, H.: Acta Chem. Scand. 4, 1490 (1950). 